\title{
FAKTOR-FAKTOR YANG MEMPENGARUHI TINGKAT KESEMBUHAN CIDERA PADA TULANG AKIBAT BENCANA
}

\author{
SRI SULASTRI \\ Email: sri.sulastri@yahoo.com
}

\begin{abstract}
The purpose of this study was to determine the Factors That Influence The Level Of Healing In Injury Bone. This research uses descriptive correlation design with cross sectional approach. This research was conducted at the Dr.Reksodiwiriyo Padang Hospital with 30 people who had long fractures and were selected based on inclusion criteria. The measuring instrument is a questionnaire that has been tested for validity and reliability. The analysis used was univariate and bivariate using the Chi Square test. The results of this study indicate that there is a significant relationship between socioeconomic status $(p$ value $=0.049)$ with patient anxiety, and there is no significant relationship between nursing services ( $p$ value $=0.440)$, level of knowledge ( $p$ value $=0.024)$, family support $(p$ value $=0.127)$ with patient anxiety. The results of this study recommend that hospitals improve psychosocial nursing care and help direct the mechanism of adaptive treatment to patients treated at the hospital thereby reducing anxiety.
\end{abstract}

Keywords: Anxiety, family sopport, knowledge, long broken bones, nursing services, socioeconomic status

\section{PENDAHULUAN}

Fraktur diartikan secara ringkas dan umum sebagai patah tulang yang disebabkan oleh trauma atau tenaga fisik, dan bisa terjadi akibat adanya tekanan yang berlebihan dibandingkan kemampuan tulang dalam menahan tekanan (Helmi, 2012). Akibat tulang tidak mampu menahan tekanan yang berlebihan menyebabkan fungsi dan struktur tulang menjadi rusak.

Berdasarkan data Rekam Medis RSUD Arifin Achmad (2013), pada tahun 2010 tercatat kasus fraktur sebanyak 628 kasus, 490 kasus di antaranya merupakan kasus fraktur tulang panjang. Penderita fraktur meningkat pada tahun 2011 dan tercatat sebanyak 671 kasus, 542 kasus di antaranya merupakan kasus fraktur tulang panjang. Penderita fraktur kembali meningkat pada tahun 2012 yaitu sebanyak 689 kasus, dan 443 kasus di antaranya merupakan kasus fraktur tulang panjang, serta pada Januari hingga Juli 2013 tercatat 481 kasus fraktur, sebanyak 248 kasus di antaranya merupakan kasus fraktur tulang panjang (Rekam Medis AA, 2013).

Berdasarkan data Rekam Medis tersebut dapat disimpulkan bahwa lebih dari $50 \%$ kasus fraktur setiap tahunnya adalah kasus fraktur tulang panjang dengan jenis fraktur yang berbeda. Urutan kasus fraktur tulang panjang terbanyak dari Januari hingga Juli 2013 yaitu fraktur femur, fraktur humerus, fraktur tibia, fraktur radius, dan fraktur ulna (Rekam Medis RSUD AA, 2013).

Upaya untuk mengembalikan struktur dan fungsi tulang menjadi normal kembali diperlukan berbagai terapi. Terapi yang diberikan pada pasien fraktur tergantung pada jenis fraktur yang dialami. Terapi yang tepat dapat mempercepat proses pemulihan. Pemulihan yang cepat salah satunya berhubungan dengan layanan keperawatan, di mana merupakan layanan kesehatan di rumah sakit yang diberikan oleh perawat sebagai teknisi yang berhubungan erat dengan pasien karena pelayanan keperawatan diberikan selama 24 jam dimulai dari awal masuk hingga kepulangan pasien. Perawat merupakan teknisi kesehatan yang paling berperan terhadap kesembuhan pasien.

Pelayanan keperawatan yang baik bergantung pada kemampuan perawat dalam memberikan jasa pelayanan. Evaluasi setiap layanan yang diberikan oleh perawat sangat penting untuk menentukan keefektifannya. Ley (1990) berfokus pada komunikasi, kepuasan, dan kepatuhan dalam kaitannya dengan dampak antara satu dengan yang lain, yang menyatakan bahwa komunikasi yang buruk antara pasien dan praktisi layanan kesehatan mengakibatkan ketidakpuasan pasien, yang berdampak buruk terhadap kemajuan dan pemulihan pasien (Kneale \& Davis, 2011). 
Hall, et al (1990) membahas dampak positif kepuasan terhadap kesehatan, menyatakan dua alasan yang mungkin. Pertama, pasien yang puas cenderung mematuhi anjuran medis dan kedua, kepuasan memiliki efek plasebo terhadap kesejahteraan psikologis yang selanjutnya memiliki efek positif terhadap kesehatan fisik. Pasien yang tidak puas akan mengalami stress dan kesembuhan, kemudian berdampak negatif terhadap kesejahteraan fisik (Kneale \& Davis, 2011).

Berdasarkan penelitian yang dilakukan oleh Sugiarto (2011), didapatkan hasil bahwa terdapat hubungan yang signifikan antara pelayanan keperawatan terhadap tingkat kepuasan pasien di Ruang Marwah RSI PKU Muhammadiyah Kabupaten Tegal. Hal ini berarti, semakin baik pelayanan keperawatan yang diberikan kepada pasien dapat meningkatkan kepuasan terhadap pasien, sehingga berdampak baik terhadap pemulihan pasien.

Pemberi layanan kesehatan dituntut untuk memberi informasi terkait penyakit dan hasil serta keefektifan klinis pasien setelah berbagai intervensi penanganan. Perawat bertanggung jawab dalam aspek pendidikan, karena perubahan tingkah laku merupakan salah satu sasaran pelayanan keperawatan (Kneale \& Davis, 2011). Perawat memberikan pendidikan dan pemahaman kepada pasien secara terorganisir dalam rangka menanamkan perilaku sehat, seperti yang diharapkan dalam mencapai tingkat kesehatan yang optimal. Pendidikan dan pemahaman yang diberikan oleh perawat kepada pasien dapat meningkatkan pengetahuan pasien mengenai penyakitnya.

Notoatmodjo (2007) menyatakan bahwa pengetahuan diperlukan sebagai dukungan dalam menumbuhkan rasa percaya diri maupun sikap dan perilaku setiap hari, sehingga dapat dikatakan bahwa pengetahuan merupakan fakta yang mendukung tindakan seseorang, dalam hal ini yaitu pengetahuan pasien mengenai fraktur. Peningkatan pengetahuan pasien mengenai fraktur akan mempengaruhi proses pengobatan sehingga pasien bersedia mengikuti terapiterapi yang diberikan, dan sebaliknya pengetahuan pasien yang rendah akan menyebabkan penundaan terapi, seperti operasi pembedahan.

Penundaan jadwal terapi menyebabkan lama hari rawat pasien fraktur akan bertambah. Penambahan lama hari rawat akan memberi

dampak biaya personal yang signifikan bagi pasien dan keluarganya serta menimbulkan kerugian secara finansial. Hal ini berpengaruh pada psikologis yang dialami pasien fraktur dan keluarganya (Kneale \& Davis, 2011). Status ekonomi yang rendah akan menyebabkan individu mudah mengalami kesembuhan (Harianto, 2008).

Penelitian yang berkaitan telah dilakukan oleh Mardiah pada tahun 2001. Penelitian ini mendapatkan hasil bahwa terdapat hubungan yang erat antara pengetahuan dan sosial ekonomi dengan tingkat kesembuhan klien pre operasi seksio sesaria. Hal ini membuktikan bahwa tingkat pengetahuan dan status ekonomi yang rendah akan meningkatkan kesembuhan pasien pra operasi.

Kesembuhan merupakan salah satu dari banyak reaksi yang sifatnya umum terhadap penyakit dan pengobatan, antisipasi atau pemeriksaan, dan penegakan diagnosis (Asmadi, 2008). Kesembuhan adalah kekhawatiran yang tidak jelas menyebar di alam dan terkait dengan perasaan ketidakpastian dan ketidakberdayaan, perasaan isolasi, keterasingan, dan

menggunakan desain kuantitatif dengan metode deskriptif korelasi menggunakan pendekatan cross sectional. Populasi ketidakamanan juga hadir (Stuart \& Laraia, 2005). Terlihat jelas bahwa kesembuhan ini mempunyai dampak terhadap kehidupan seseorang.

Kesembuhan yang dirasakan pasien fraktur dapat memperberat penyakit fisik. Pasien harus mampu mengatasi kesembuhan tersebut agar penyakit fisik yang dialaminya tidak bertambah parah. Respon cemas yang terjadi pada penderita fraktur sangat berkaitan sekali dengan mekanisme koping yang dimilikinya. Mekanisme koping yang baik akan membentuk respon psikologis yang baik yang berperan dalam menunjang proses kesembuhan. Dukungan keluarga merupakan faktor penting yang dibutuhkan seseorang dalam menghadapi masalah dan suatu strategi koping yang sangat baik untuk mengurangi rasa cemas yang berlebihan. Dukungan keluarga dan melibatkan orang terdekat selama perawatan berpengaruh terhadap mental seseorang dan dapat meminimalkan efek gangguan psikososial (Saryono, 2008).

Penelitian berkaitan telah dilakukan oleh Badar pada tahun 2013. Penelitian ini mendapatkan hasil bahwa terdapat hubungan yang kuat antara dukungan keluarga dengan tingkat kesembuhan pasien fraktur di ruang rawat

reksodiwiriyo padang. Jadi, semakin tinggi dukungan keluarga maka semakin rendah tingkat kesembuhan pasien, sehingga dukungan keluarga sangat diperlukan bagi pasien fraktur.

Berdasarkan studi pendahuluan yang telah dilakukan pada tanggal 17 Februari 2018 pada 10 orang pasien yang dirawat di ruang Ruang inap Rs.reksodiwiriyo padang menangani kasus bedah saraf, bedah anak, bedah kepala leher, bedah umum, bedah urologi, dan orthopedi.

Dengan melalui metode wawancara, diperoleh data bahwa 8 dari 10 orang yang mengalami fraktur tulang panjang memiliki perasaan cemas dan khawatir. Cemas yang dirasakan berhubungan dengan kondisi fisiknya saat ini, biaya pengobatan yang salah satunya dikarenakan lamanya hari perawatan, prosedur medis yang sedang dijalani dan yang akan dilaksanakan seperti operasi pembedahan, kondisi fisik setelah dilakukan proses pembedahan, kegagalan operasi, dan kondisi kehidupan keluarga yang ditinggalkan.

Peneliti juga memiliki pengalaman dengan seorang pasien fraktur yang akan menjalani operasi. Kesembuhan semakin meningkat saat jadwal operasi semakin dekat. Jadwal operasi pasien tersebut harus ditunda karena kesembuhan yang dirasakan semakin tinggi. Perasaan cemas dipengaruhi oleh ketakutan menghadapi rasa sakit, dan bagaimana proses pembedahan. Penundaan jadwal operasi ini berdampak pada proses pemulihan pasien.

Sebagian pasien sering bertanya apakah bentuk dari fisiknya dapat kembali seperti semula, dan setelah kesehatan fisik telah stabil, pasien masih merasakan kesembuhan dan rasa takut yang terkait dengan sakit akut. Kesembuhan yang dirasakan pasien ditandai dengan frekuensi nadi yang cepat, jantung yang berdebar-debar, peningkatan pernapasan, susah tidur dan mulut kering. Jadi, dapat disimpulkan bahwa banyak fak inap Rs.

yang mempengaruhi kesembuhan pasien fraktur tulang panjang.

Berdasarkan fenomena-fenomena yang telah diuraikan di atas, banyaknya alasan yang melatarbelakangi kesembuhan pada pasien fraktur tulang membuat peneliti tertarik untuk mengetahui faktor-faktor yang mempengaruhi tingkat kesembuhan cidera padatulang akibat bencana .

dalam penelitian ini adalah semua pasien fraktur tulang panjang yang dirawat

Metode pengambilan sampel yang digunakan purposive 
sampling, yaitu peneliti memilih sampel dari populasi tersedia sesuai dengan kriteria yang telah ditetapkan oleh peneliti sendiri (Wood \& Haber, 2006). Peneliti hanya mengambil responden sesuai dengan kriteria inklusi.

Data yang diperoleh dalam penelitian ini berasal dari data primer dan data sekunder yang diambil dari catatan medis pasien.. Data primer menggunakan metode kuesioner yang dibuat sendiri oleh peneliti dan telah dilakukan uji validitas dan reliabilitas kuesioner. Jenis pertanyaan dan pernyataan ini dirancang terstruktur yang terdiri dari kuesioner karakteristik responden, layanan keperawatan, tingkat pengetahuan, status sosial ekonomi, dukungan keluarga, dan kesembuhan.

Kuesioner kesembuhan menggunakan alat ukur kesembuhan yang disebut Hamilton Rating Scale For Anxiety (HRS-A). Skala HRS-A pertama kali digunakan pada tahun 1959, yang diperkenalkan oleh Max Hamilton dan sekarang telah menjadi standar dalam pengukuran kesembuhan. Skala HRS-A terdiri dari 14 pernyataan yang merupakan tanda dan gejala serta respon yang ditunjukkan dari kesembuhan (Hawari, 2008). Skala HRS-A telah dibuktikan memiliki validitas dan reliabilitas cukup tinggi untuk melakukan pengukuran kesembuhan yaitu 0,93 dan 0,97 . Kondisi ini menunjukkan bahwa pengukuran kesembuhan dengan menggunakan

Analisa data yang digunakan yaitu analisa univariat dan analisa bivariat. Analisa univariat bertujuan untuk menjelaskan atau mendeskripsikan karakteristik responden, dan masingmasing variabel penelitian (tingkat kesembuhan, layanan keperawatan, tingkat pengetahuan, status sosial ekonomi, dan dukungan keluarga). Analisa bivariat digunakan untuk mengetahui hubungan antara dua variabel, yaitu variabel independen (layanan keperawatan, tingkat pengetahuan, status sosial ekonomi, dukungan keluarga) dan variabel dependen (kesembuhan).

skala HRS-A akan diperoleh hasil yang valid dan reliabel. dan didapatkan hasil

Analisa Univariat Karakteristik Responden

Tabel 1.

Distribusi Frekuensi Responden Berdasarkan Umur, Jenis Kelamin, Pendidikan Terakhir, Pekerjaan, Diagnosa Medis, Lama Hari Rawat dan Frekuensi Masuk Rumah Sakit $(\mathbf{n}=$ 30)

\begin{tabular}{llll}
\multicolumn{5}{c}{ Penelitian } & $(\mathrm{F})$ & $(\%)$ \\
\hline \multicolumn{5}{c}{ Tingkat Kesembuhan } \\
\hline 1. & Kesembuhan Sedang & 17 & 56,7 \\
\hline 2. & Kesembuhan Ringan & 13 & 43,3 \\
\hline \multicolumn{5}{l}{ Layanan Keperawatan } \\
\hline 1. & Negatif 10 & 33,3 \\
\hline 2. & Positif 20 & 66,7
\end{tabular}

Tingkat Pengetahuan

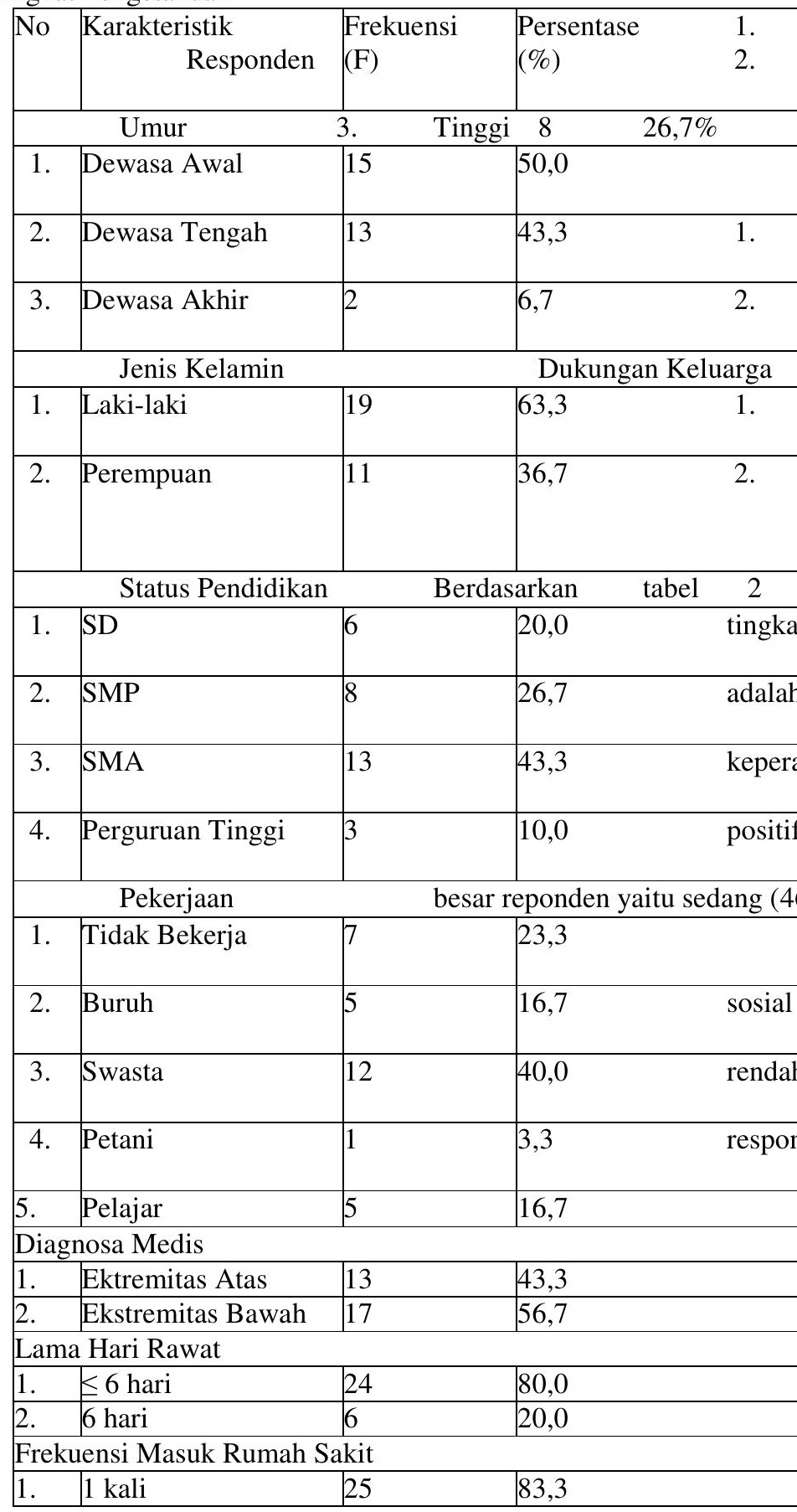


Berdasarkan tabel 1 diketahui bahwa sebagian besar responden berada pada usia dewasa awal (50\%), jenis kelamin sebagian besar responden yaitu laki-laki $(63,3 \%)$, status pendidikan sebagian besar reponden yaitu SMA (43,3\%), pekerjaan responden sebagian besar adalah swasta (40\%), diagnosa medis responden sebagian besar adalah fraktur ekstremitas bawah $(56,7 \%)$, lama hari rawat responden sebagian besar adalah $\leq 6$ hari $(80 \%)$, dan frekuensi masuk rumah sakit responden sebagian besar adalah 1 kali $(83,3 \%)$.

Karakteristik Variabel-variabel Penelitian

Tabel 2.

Distribusi Frekuensi Responden Berdasarkan Tingkat Kesembuhan, Layanan keperawatan, Tingkat Pengetahuan, Status Sosial Ekonomi, dan Dukungan Keluarga $(\mathrm{n}=30)$ 
nalisa Bivariat

Tabel 3.

Hubungan antara Layanan Keperawatan, Tingkat Pengetahuan, Status Sosial Ekonomi, dan Dukungan Keluarga dengan Tingkat Kesembuhan $(\mathrm{n}=30)$

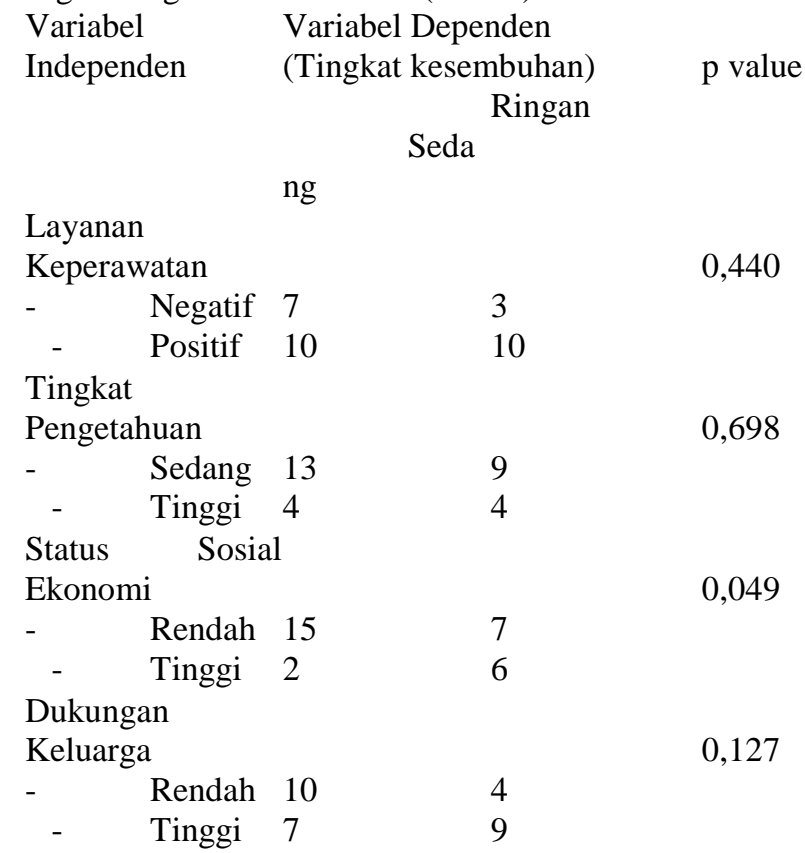

Berdasarkan tabel 3 diketahui bahwa hubungan antara layanan keperawatan dengan kesembuhan didapatkan $\mathrm{p}$ value $0,440>$ $\alpha$ 0,05. Hal ini berarti Ho gagal ditolak, maka dapat disimpulkan bahwa tidak ada hubungan antara layanan keperawatan dengan kesembuhan responden. Hubungan antara tingkat pengetahuan dengan kesembuhan didapatkan $\mathrm{p}$ value $0,698>\alpha 0,05$. Hal ini berarti Ho gagal ditolak, maka dapat disimpulkan bahwa ada tidak hubungan antara tingkat pengetahuan dengan kesembuhan responden. Hubungan antara status sosial ekonomi dengan kesembuhan didapatkan $\mathrm{p}$ value $0,049<\alpha 0,05$. Hal ini berarti Ha gagal ditolak, maka dapat disimpulkan bahwa ada hubungan antara status sosial ekonomi dengan kesembuhan responden. Hubungan antara dukungan keluarga dengan kesembuhan didapatkan $\mathrm{p}$ value $0,127>\alpha$ 0,05 . Hal ini berarti Ho gagal ditolak, maka dapat disimpulkan bahwa tidak ada hubungan antara dukungan keluarga dengan kesembuhan responden.

\section{PEMBAHASAN}

Analisa Univariat

Karakteristik Responden

Berdasarkan hasil penelitian didapatkan bahwa sebagian besar responden berada pada rentang usia dewasa awal (18-25 tahun) (50\%). Hal ini didukung oleh pernyataan Sjamsuhidayat dan Jong (2005) bahwa fraktur cenderung terjadi pada umur di bawah 45 tahun dan sering berhubungan dengan olahraga, pekerjaan, atau luka yang disebabkan oleh kendaraan bermotor. Kelompok umur dewasa awal lebih banyak melakukan aktivitas yang berat daripada kelompok umur dewasa akhir. Aktivitas yang banyak akan cenderung mengalami kelelahan tulang dan jika ada trauma benturan atau kekerasan tulang bisa saja patah. Aktivitas masyarakat umur dewasa awal di luar rumah cukup tinggi dengan pergerakan yang cepat pula sehingga dapat meningkatkan risiko terjadinya benturan atau kecelakaan yang menyebabkan fraktur.

Berdasarkan jenis kelamin didapatkan bahwa sebagian besar adalah laki-laki $(63,3 \%)$. Hal ini sejalan dengan pendapat Sjamsuhidajat dan Jong (2005) yang menyatakan bahwa fraktur cenderung terjadi pada laki-laki dan sering berhubungan dengan olahraga, pekerjaan, atau luka yang disebabkan oleh kendaraan bermotor. Hal ini diasumsikan karena laki-laki lebih sering keluar rumah dengan mobilitas yang tinggi dan menggunakan kendaraan bermotor. Mobilisasi yang lebih banyak dilakukan oleh laki-laki menjadi penyebab tingginya risiko fraktur.

Berdasarkan status pendidikan didapatkan bahwa sebagian besar adalah SMA (43,3\%). Kejadian fraktur bisa terjadi pada individu dengan tingkat pendidikan tinggi maupun tingkat pendidikan rendah. Hal ini sesuai dengan hasil penelitian yang dilakukan oleh Syahputra (2013) yang menyatakan bahwa secara umum distribusi responden fraktur tulang panjang berdasarkan status pendidikan terbanyak adalah status pendidikan SMA yang berjumlah 16 responden.

Berdasarkan jenis pekerjaan didapatkan bahwa sebagian besar adalah swasta (40\%). Kejadian fraktur bisa terjadi pada orang yang bekerja maupun tidak bekerja, namun tergantung pada aktivitas yang dilakukan. Pada penelitian ini ditemukan pekerjaan responden yang paling banyak adalah bergerak di bidang swasta. Namun jika karakteristik pekerjaan dikategorikan menjadi bekerja dan tidak bekerja, maka jumlah kasus fraktur terbanyak terjadi pada responden yang bekerja berjumlah 23 responden. Sehingga dapat diasumsikan bahwa orang yang bekerja lebih berisiko mengalami fraktur. Hal ini karena orang yang bekerja memiliki mobilisasi yang tinggi di luar rumah, sedangkan yang tidak bekerja lebih tidak berisiko karena hanya 
beraktivitas di rumah atau tidak beraktivitas di luar tempat tinggal (Mock \& Charles, 2005).

Berdasarkan diagnosa medis didapatkan bahwa sebagian besar fraktur ekstremitas bawah (56,7\%). Salah satu insiden kecelakaan yang memiliki prevalensi cukup tinggi yakni insiden fraktur ekstremitas bawah (46,2\%) (Depkes RI, 2009). Hal ini sejalan dengan penelitian yang dilakukan oleh Eldawati (2011) di RSUP Fatmawati Jakarta yang menyatakan bahwa jenis fraktur yang banyak terjadi yaitu fraktur ekstremitas bawah, seperti fraktur femur, fraktur tibia, dan fraktur fibula.

Berdasarkan lama hari rawat didapatkan bahwa sebagian besar $\leq 6$ hari (80\%). Permasalahan yang sering terjadi pada fraktur di antaranya perdarahan. Kondisi kurang darah atau kurang suplai oksigen memungkinkan pasien fraktur akan merasa lebih lemah (Black \& Hawks, 2009). Apabila kondisi pasien masih dalam keadaan lemah, maka proses pengobatan akan terus dilanjutkan sehingga menyebabkan lama hari rawat akan bertambah. Faktor lain yang mempengaruhi lama hari rawat responden adalah jadwal operasi. Jadwal operasi yang banyak di RSUD Arifin Achmad Pekanbaru menambah antrian bagi penderita fraktur baru yang akan dilakukan tindakan operasi.

Berdasarkan frekuensi masuk rumah sakit didapatkan bahwa sebagian besar 1 kali $(83,3 \%)$. Frekuensi masuk rumah sakit yang lebih dari satu kali atau dua kali pada beberapa responden disebabkan karena riwayat penyakit sebelumnya, seperti gastritis ataupun riwayat kecelakaan sebelumnya.

\section{Analisa Bivariat}

Hubungan antara layanan keperawatan dengan kesembuhan didapatkan $\mathrm{p}$ value $0,440>\alpha 0,05$. Hal ini berarti Ho gagal ditolak, maka dapat disimpulkan bahwa tidak ada hubungan antara layanan keperawatan dengan kesembuhan responden. Peneliti mengasumsikan bahwa responden yang telah memberikan penilaian positif terhadap layanan keperawatan, namun masih memiliki kesembuhan karena adanya faktor lain, seperti ketidakpastian jadwal operasi dan jarangnya kunjungan dokter, serta sarana dan prasarana di ruangan, seperti tidak adanya televisi ataupun radiotape, sehingga responden selalu memikirkan hal-hal yang dapat menambah beban pikiran sehingga menimbulkan kesembuhan. Hasil penelitian ini tidak sejalan dengan penelitian yang dilakukan oleh Nuralita (2002) yang mendapatkan hasil bahwa ada hubungan yang negatif antara persepsi layanan keperawatan di rumah sakit dengan kesembuhan pasien rawat inap. Hal ini berarti semakin baik persepsi layanan pasien rawat inap terhadap layanan keperawatan di rumah sakit, semakin rendah kesembuhan pasien rawat inap. Sebaliknya, bila semakin rendah persepsi pasien rawat inap terhadap layanan keperawatan di rumah sakit, semakin tinggi kesembuhan pasien rawat inap.

Hubungan antara tingkat pengetahuan dengan kesembuhan didapatkan $\mathrm{p}$ value $0,698>\alpha 0,05$. Hal ini berarti Ho gagal ditolak, maka dapat disimpulkan bahwa ada tidak hubungan antara tingkat pengetahuan dengan kesembuhan responden. Asmadi (2008) menyatakan bahwa sebagian orang yang mengetahui penyakitnya secara baik justru akan meningkatkan kesembuhannya, dan sebaliknya pada orang yang mengetahui penyakitnya dengan minim justru membuatnya semakin tenang. Hal ini tergantung terhadap persepsi atau penerimaan responden itu sendiri terhadap penyakit yang dideritanya, mekanisme pertahanan diri dan mekanisme koping yang digunakan. Hasil penelitian ini sejalan dengan penelitian yang dilakukan oleh Kuraesin (2009) didapatkan hasil bahwa tidak ada hubungan yang signifikan antara tingkat pengetahuan dengan tingkat kesembuhan pasien di ruang rawat bedah RSUP Fatmawati. Hal ini karena setiap ada stressor yang menyebabkan individu merasa cemas, maka secara otomatis muncul upaya untuk mengatasinya dengan berbagai mekanisme koping, sehingga mereka mampu mengatasi kesembuhan yang dirasakan.

Hubungan antara status sosial ekonomi dengan kesembuhan didapatkan $\mathrm{p}$ value $0,049<\alpha 0,05$. Hal ini berarti Ha gagal ditolak, maka dapat disimpulkan bahwa ada hubungan antara status sosial ekonomi dengan kesembuhan responden. Hal ini sejalan dengan penelitian yang dilakukan oleh Yunitasari (2012) di RSUP Dr. Kariadi Semarang, didapatkan hasil bahwa terdapat pengaruh antara status sosial ekonomi terhadap kesembuhan pasien pasca diagnosis kanker. Status ekonomi yang rendah akan menyebabkan individu mudah mengalami kesembuhan (Harianto, 2008). Hasil penelitian ini didukung oleh pendapat Hawari (2006) yang menyatakan bahwa status sosial ekonomi berhubungan dengan pendapatan keluarga. Sebagian besar kepala keluarga dalam penelitian ini memiliki tingkat pendidikan yang rendah, seperti SD dan SMP yang bekerja dengan penghasilan di bawah UMR, yaitu kurang dari Rp. 1.775.000,00 perbulan. Adanya hubungan antara status sosial ekonomi dengan tingkat kesembuhan dalam penelitian ini disebabkan karena masih ada responden yang tidak menggunakan asuransi kesehatan, dan kebutuhan pasien selama masa perawatan meningkat sehingga pasien banyak memikirkan biaya yang harus dikeluarkan.

Hubungan antara dukungan keluarga dengan kesembuhan didapatkan $\mathrm{p}$ value $0,127>\alpha 0,05$. Hal ini berarti Ho gagal ditolak, maka dapat disimpulkan bahwa tidak ada hubungan antara dukungan keluarga dengan kesembuhan responden. Peneliti mengasumsikan bahwa responden yang mendapatkan dukungan keluarga tinggi masih memiliki kekhawatiran terkait fraktur yang dialaminya, meskipun semua aspek dari 
dukungan keluarga telah diterima responden.

\section{KESIMPULAN}

Berdasarkan hasil penelitian yang dilakukan terhadap 30 responden fraktur tulang panjang pra operasi yang dirawatsecara statistik didapatkan hasil bahwa sebagian besar responden berada pada rentang usia dewasa awal (18-25 tahun) sebanyak 15 responden. Berdasarkan jenis kelamin sebagian besar responden yaitu laki-laki sebanyak 19 responden. Berdasarkan status pendidikan sebagian besar responden yaitu tingkat pendidikan SMA sebanyak 13 responden. Berdasarkan pekerjaan sebagian besar responden yaitu swasta sebanyak 12 responden. Berdasarkan diagnosa medis sebagian besar responden yaitu fraktur ekstremitas bawah sebanyak 17 responden. Berdasarkan lama hari rawat sebagian besar responden yaitu $\leq 6$ hari sebanyak 24 responden. Berdasarkan frekuensi masuk rumah sakit sebagian besar responden yaitu 1 kali sebanyak 25 responden.

Berdasarkan hasil gambaran variabel penelitian, gambaran tingkat kesembuhan sebagian besar responden yaitu sedang sebanyak 17 responden. Gambaran layanan keperawatan sebagian besar responden memberikan penilaian positif sebanyak 20 responden. Gambaran tingkat pengetahuan sebagian besar responden yaitu sedang sebanyak 14 responden. Gambaran status sosial ekonomi sebagian besar responden yaitu rendah sebanyak 22 responden. Gambaran dukungan keluarga sebagian besar responden yaitu tinggi sebanyak 16 responden.

Berdasarkan uji statistik terhadap faktor- faktor yang mempengaruhi tingkat kesembuhan pasien fraktur tulang panjang pra operasi yang dirawat pada faktor layanan keperawatan diperoleh $\mathrm{p}$ value 0,440 , pada nilai $\alpha 0,05$ yang berarti $\mathrm{p}$ value

$\alpha 0,05$, sehingga didapatkan kesimpulan tidak ada hubungan yang signifikan antara layanan keperawatan dengan kesembuhan responden. Hasil uji statistik terhadap faktor tingkat pengetahuan diperoleh $\mathrm{p}$ value 0,698 , pada nilai $\alpha 0,05$ yang berarti $p$ value $>\alpha 0,05$, sehingga didapatkan kesimpulan ada tidak hubungan yang signifikan antara tingkat pengetahuan dengan kesembuhan responden. Hasil uji statistik terhadap faktor status sosial ekonomi diperoleh $\mathrm{p}$ value 0,049 , pada nilai $\alpha 0,05$ yang berarti $\mathrm{p}$ value $<\alpha 0,05$, sehingga didapatkan kesimpulan ada hubungan yang signifikan antara status sosial ekonomi dengan kesembuhan responden. Hasil uji statistik terhadap faktor dukungan keluarga diperoleh $\mathrm{p}$ value 0,127 , pada nilai $\alpha 0,05$ yang berarti $p$ value

$\alpha 0,05$, sehingga didapatkan kesimpulan tidak ada hubungan yang signifikan antara dukungan keluarga dengan kesembuhan responden.

\section{SARAN}

Bagi ilmu keperawatan hasil penelitian dapat menjadi suatu bahan masukan dan sumber informasi bagi ilmu keperawatan dalam pengembangan ilmu pengetahuan khususnya bagi mata ajar Keperawatan Dasar.

Selanjutnya, bagi institusi rumah sakit lebih meningkatkan kembali dalam memberikan asuhan keperawatan psikososial kepada pasien yang dirawat inap dan membantu pasien mengarahkan mekanisme koping yang adaptif, serta memberikan dukungan dan penjelasan tentang prosedur yang akan dilalui pasien sehingga kesembuhan pasien dapat berkurang. Institusi rumah sakit juga dapat melakukan modifikasi lingkungan seperti memberikan fasilitas televisi 
merasa lebih nyaman berada di lingkungan rumah sakit dan dapat menurunkan kesembuhan.

Bagi peneliti selanjutnya dapat menggunakan kuesioner kesembuhan yang lebih spesifik lagi khusus diajukan bagi pasien fraktur, dan dapat melanjutkan penelitian yang lebih spesifik lagi dengan menghubungkan variabel- variabel yang tidak berhubungan dalam penelitian ini, seperti variabel layanan keperawatan dan dukungan keluarga terhadap kesembuhan pasien yang dirawat inap. Peneliti selanjutnya juga bisa menambahkan variabel sarana dan prasarana.

\section{DAFTAR PUSTAKA}

Asmadi. (2008). Teknik prosedural keperawatan: Konsep dan aplikasi kebutuhan dasar klien. Jakarta: Salemba Medika.

Badar, M. (2013). Hubungan dukungan keluarga dengan tingkat kesembuhan pada pasien fraktur di ruang rawat inap Lontara II RSUP Dr. Wahidin Sudirohusodo Makassar. Diperoleh pada tanggal 6 Maret 2014 dari library.stikesnh.ac.id.

Black, J. M., \& Hawks, J. H. (2009). Medical surgical nursing: Clinical management for positive outcomes. Eight Edition. Missouri: Elsevier Saunders.

Depkes RI. (2009). Penyakit tidak menular vol 1. Diperoleh pada tanggal 26 Juni 2014 dari http://litbang.depkes.go.id. Eldawati. (2011). Pengaruh latihan kekuatan otot pre operasi terhadap kemampuan ambulasi dini pasien pasca operasi fraktur ekstremitas bawah di RSUP Fatmawati Jakarta. Diperoleh pada tanggal $29 \quad$ Juni 2014 dari http://lontar.ui.ac.id/file?file=digital/2028 $0665-$ T\%20Eldawati.pdf.

Ginting, D. (2006). Pelayanan prima. Medan: RSUP H. Adam Malik Medan.

Harianto. (2008). Analisis status sosial masyarakat dan dampaknya terhadap partisipasi politik di Kelurahan Karangrejo Kecamatan Karangrejo Kabupaten Magetan. Jurnal Sosial UNMER Madiun, 9 (2), 18-23. ospitalia.rskariadi.co.id. 